\section{Brinell-hardness testing and discrete element modelling of hardened concrete}

Zoltán GYURKó

(1989) civil engineer (MSC), PhD candidate at the BME Dept. of Construction Materials and Technologies. Main fields of interest: non-destructive testing of concrete and porous building materials, Discrete Element Modelling.

ZoLTÁN GYURKÓ - PhD candidate - BME Dept. of Consruction Materials and Technologies - gyurko.zoltan@epito.bme.hu

AdorJán BOROSNYÓl - Assocoate Professor - BME Dept. of Consruction Materials and Technologies - borosnyoi.adorjan@epito.bme.hu

Érkezett: 2015. 01. 12. " Received: 12. 01. 2015. - http://dx.doi.org/10.14382/epitoanyag-jsbcm.2015.2

\section{Abstract}

Present paper deals with the Brinell-hardness testing of hardened concrete and with the Discrete Element Method (DEM) modelling of this type of experiment to get a better understanding of the behaviour of porous solid materials under a penetrating spherical body. Discrete Element Method is a powerful tool to model porous solid materials like concrete, which allows visualizing the movements inside the material that are formed during the test. This helps to better observe and understand the material behaviour and the special characteristics of hardness testing.

Keywords: Brinell-hardness, Discrete Element Method, concrete, porous solids, indentation test.
Dr. Adorján BOROSNYó

(1974) civil engineer (MSc), PhD, associate professor at the BME Dept. of Construction Materials and Technologies. Main fields of interest: application of non-metallic (FRP) reinforcements for concrete structures, bond in concrete, non-destructive testing of concrete. Member of the Hungarian Group of fib and of fib TG 4.1 "Serviceability Models". Member of RILEM Technical Committee ISC "Non-destructive in situ strength assessment of concrete".

\section{Introduction}

According to Hertz, hardness can be defined as the least value of pressure under a spherical indenter necessary to produce a permanent set at the center of the area of contact [1]. The definition of Hertz has some practical difficulties, therefore, the value of hardness is defined in practice by various ways. Mostly these practical definitions indicate different relationships between the loading force and the resistance of the material against penetration or permanent deformation.

Nowadays, the so called indentation hardness test methods are the most commonly used techniques to measure the surface hardness of a material. The indentation hardness test methods can be divided into two groups based on the mechanical behaviour of the process: static and dynamic methods. Dynamic processes like rebound hammer measurements or Leeb-hardness testing are faster than static processes (e.g. Brinell- or Vickers-test), but less reliable. If one intends to examine hardness in a sophisticated way then static processes are more appropriate.

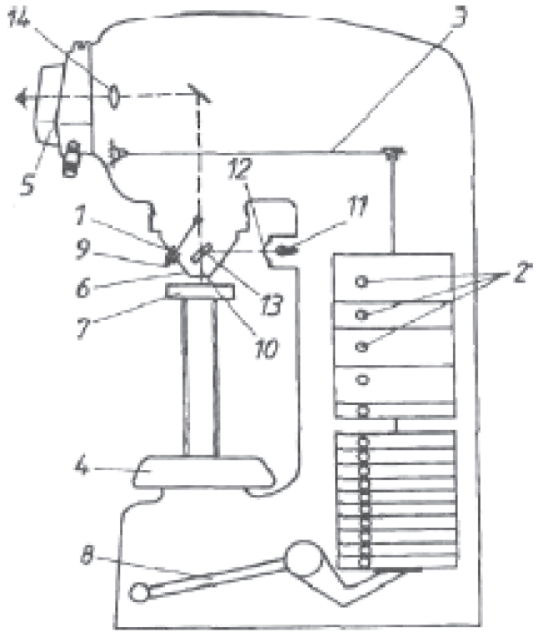

Fig. 1. Schematic figure of a Brinell-hardness tester [2] 1. ábra Brinell keménység vizsgáló készülék sematikus rajza [2]
The most well-known static indentation hardness testing method is the Brinell-test that can be performed as DSI (Depth Sensing Indentation) test as well [2]. During Brinell-hardness testing (Fig. 1), a hardened, polished steel ball is pressed into the surface of the tested material at a specified loading rate, maximum load and time. The test applies a constant loading force, usually 500 to $3000 \mathrm{~kg}$ (depending on the tested material), by a $10 \mathrm{~mm}$ diameter hardened steel ball to the flat surface of a specimen. The load is applied for a specified time (that is different for different types of materials; for a soft metal it is between 10-15 seconds, for a hard metal it is usually 30 seconds). The duration of load is required for the final deformations in the material to be developed. The aim of the process is to have a hardness value, which is calculated from the diameter of the ball print created by the indenter.

\section{The Discrete Element Method}

The Discrete Element Method (DEM) is a group of numerical methods, of which the first type (the so called distinct element method) was introduced by Cundall [3] in 1971. DEM is a powerful tool for the modelling of grains, soil, masonry structures and other applications, where the elements of the modelled structure or material are not connected to each other at the material level. DEM was already introduced earlier in more details by the authors of the present paper [4].

The DEM software PFC $3 D$ (Particle Flow Code) was used to model the process of hardness testing, which has many advantages in the field of modelling porous materials. As most of the discrete element software packages, $P F C 3 D$ is also built up from particles (discrete elements) and the contacts among them [5-10]. In this case discrete elements are assumed to be sphere shaped and completely rigid, thus the deformations of the material can be derived from the contact forces by using Newton's second law of motion.

The contacts between the particles are simulated with the so called parallel bonds, which provide the force-displacement behaviour of a finite-sized piece of cementitious material 
deposited between two balls. These bonds establish an elastic interaction between particles that acts in parallel with the slip or contact-bond forces. Parallel bonds can transmit both forces and moments between particles, while contact bonds can only transmit forces acting at the contact point. Thus, parallel bonds may contribute to the resultant force and moment acting on the two bonded particles. A parallel bond can be characterised as a set of elastic springs with constant normal and shear stiffness, uniformly distributed over a circular cross-section lying on the contact plane and centered at the contact point (Fig. 2). These springs act parallel with the point-contact springs that are used to model particle stiffness at a point. Relative motion at the contact causes a force and a moment to develop within the bond zone of the material as a result of the parallel-bond stiffness. This force and moment act on the two bonded particles.

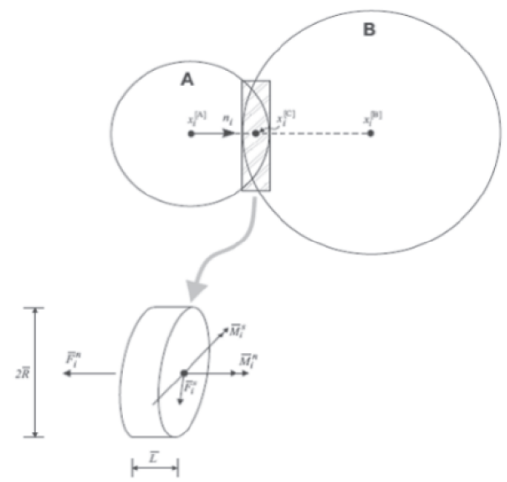

Fig. 2. Parallel bond depicted as a cylinder of cementitious material [10]

2. ábra Párhuzamos belsö kötőerő modellje hengeres alakú cementáló közegként [10]

\section{Model of the hardness testing procedure}

The main aim of the present research was to model Brinellhardness testing with DEM. During the numerical simulations, a steel sphere of $10 \mathrm{~mm}$ diameter was penetrated into the surface of a cubic concrete specimen. The penetrating steel ball was modelled as one large particle (Fig. 3); this assumption implies that the stiffness of the steel ball is much higher than the stiffness of the concrete specimen.

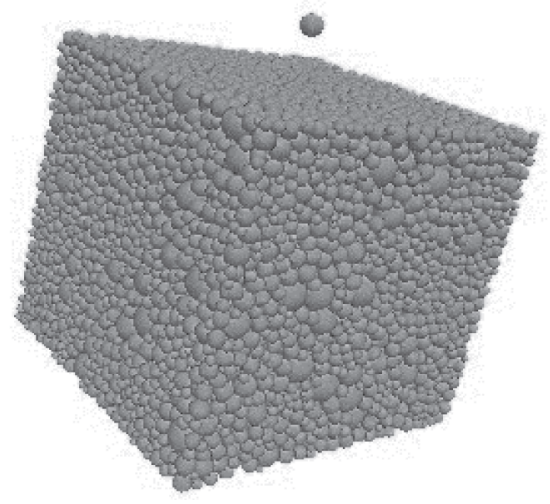

Fig. 3. The model of a concrete specimen with the steel sphere in the initial phase in perspective view

3. ábra Beton próbatest modelljének perspektivikus képe a terhelö acél golyóval

The concrete was modelled with a large number of particles (discrete elements). The size distribution of the discrete elements in the model of the concrete was the same as the particle size distribution of the aggregate in the real material. In the model the particle size distribution of the real material was followed by defining particle size classes. The maximum aggregate size was $16 \mathrm{~mm}$, and the applied aggregate size distribution was between the $\mathrm{A}$ and $\mathrm{C}$ limit grading curves suggested by Hungarian standards, which means, it is an aggregate that is suitable for concrete.

To model the steel sphere an individual particle was generated above the concrete specimen. After the steel sphere was generated, it was fixed in every direction and against rotation, since during the Brinell-hardness test the steel ball is fixed. It is also necessary to define geometry and material properties of the ball: density, size and position. Since the steel ball is generated above the concrete specimen, it is important to avoid initial contacts between the particles (and also to model precisely the Brinell-method), therefore, the steel ball should be slowly moved towards the surface of the concrete specimen. There are several ways to accomplish this movement. One way is to give an initial velocity to the ball in a given direction and run some calculation cycles until the ball almost touches the surface of the specimen. Once the ball is sufficiently close to the surface of the specimen, the loading force can be applied. In case of Brinell-testing, it is possible to apply the force in different magnitudes. When the force is applied to the steel ball it penetrates into the surface of the specimen. The Brinell-test can be carried out with different forces from $1.5 \mathrm{kN}$ to $30 \mathrm{kN}$, by changing the testing load.

When the loading phase of the simulation is finished, the force should be applied in the opposite direction, still perpendicular to the surface of the specimen, to model the unloading phase. Thus the steel ball is removed from the specimen. When the steel ball is removed and the particles of the specimen are brought into a steady state, the test is finished.

When the hardness testing procedure is finished (the steel ball is moved sufficiently away from the specimen), with the help of the measuring tool provided by the software, the distance between the edges of the residual ball print in two diagonals, which are perpendicular to each other, can be measured (this is a standard procedure in the measurement of indentation diameter). Another option is the measurement of the indentation depth of the imprint and converting it into diameter with a given formula.

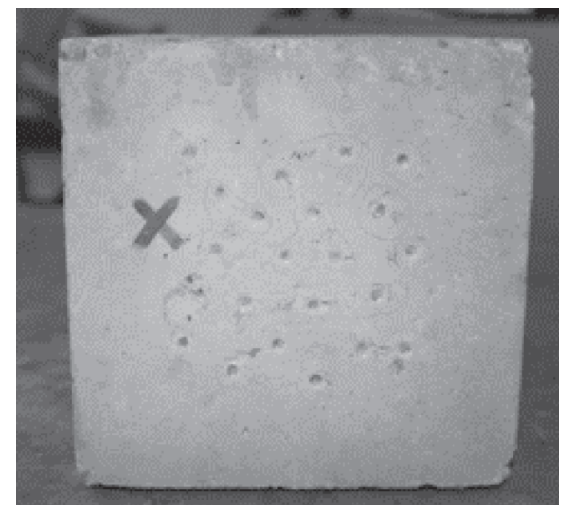

Fig. 4. Results of the Brinell-hardness test on the surface of a specimen. 4. ábra Brinell keménység mérés eredménye egy próbatest felületén. 
To represent the statistical nature of the results, several models were created during the present numerical studies, which had the same grading properties of the particles, but the random arrangement of the discrete elements was different in each case. Figs. 4 and 5, together with Tables 1 to 3 represent the averaged values of the measured results that are compared with the laboratory experiment results. Table 1 gives the indentation diameters resulted from the discrete element model.

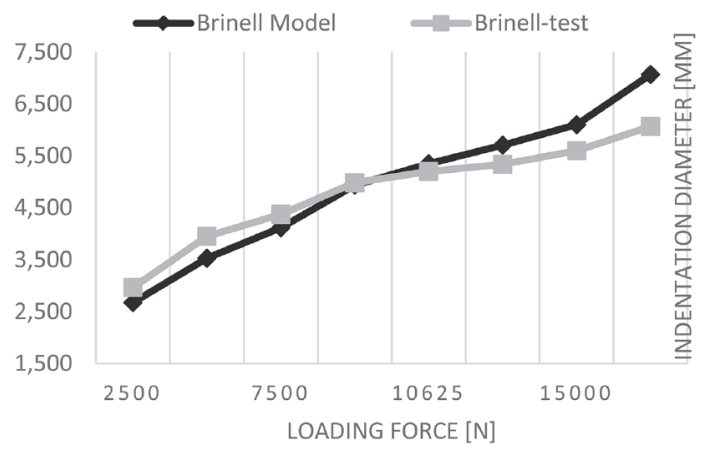

Fig. 5. Indentation diameter (model + Brinell test) vs. loading force

5. ábra Benyomódási átmérö (DEM modell + Brinell vizsgálat) és terhelöerö összefüggése

Loading force [N] Averaged indentation diameter [mm]

\begin{tabular}{ll}
2500 & 2.676 \\
\hline 5000 & 3.529 \\
\hline 7500 & 4.117 \\
\hline 10000 & 4.934 \\
\hline 10625 & 5.348 \\
\hline 12500 & 5.707 \\
\hline 15000 & 6.099 \\
\hline 17500 & 7.067
\end{tabular}

Table 1. The loading forces and the corresponding indentation diameters from the DEM model

1. táblázat A terhelőerők és a benyomódási átmérök a DEM modell alapján

\section{Laboratory experiments}

To validate the DEM model results, laboratory tests were carried out. The tests were conducted at the Budapest University of Technology and Economics, Faculty of Civil Engineering, Department of Construction Materials and Technologies. Every test was carried out under the same conditions and using the same testing device. The tests were performed on four surfaces of concrete cubes, which were originally located vertically in the formwork during specimen preparation (the other two sides were not suitable for the test, because their surfaces were not sufficiently uniform). In case of the Brinell-hardness test the measurements were made in different load increments. Five test repetitions were carried out at each load level complying with the rules of Brinell-hardness testing (e.g. taking care of the minimum distance of the prints from each other and from the edge of the specimen). To receive a statistically correct result the diameter of the ball prints at each load level was averaged. The maximum loading force was applied on the surface of the material for 30 seconds. A hand microscope was used to read the size of the prints which has a built-in ruler with precision of $0.1 \mathrm{~mm}$. Diameter readings were taken on each print in two directions (perpendicular to each other). The result came from the average of these two measurements. Table 2 contains the results of the Brinellhardness tests.

Loading force [N] Averaged indentation diameter [mm]

\begin{tabular}{cc}
2500 & 2.967 \\
\hline 5000 & 3.950 \\
\hline 7500 & 4.375 \\
\hline 10000 & 4.983 \\
\hline 10625 & 5.200 \\
\hline 12500 & 5.337 \\
\hline 15000 & 5.600 \\
\hline 17500 & 6.067
\end{tabular}

Table 2. The loading forces and the corresponding indentation diameters from the Brinell-test

2. táblázat A terhelőerők és a benyomódási átmérők a Brinell vizsgálatok alapján

During the present experiments a steel ball of diameter of 10 $\mathrm{mm}$ was used, therefore, the maximum possible indentation diameter was $10 \mathrm{~mm}$. The experiment can be considered not successful, if the applied load is too large for the material (e.g. a large force to a very soft material) and the ball penetrates into the surface of the material with more than the half of the sphere.

\begin{tabular}{cc} 
Loading force [N] & Averaged indentation diameter [mm] \\
\hline 2500 & 2.967 \\
\hline 5000 & 3.950 \\
\hline 7500 & 4.375 \\
\hline 10000 & 4.983 \\
\hline 10625 & 5.200 \\
\hline 12500 & 5.337 \\
\hline 15000 & 5.600 \\
\hline 17500 & 6.067 \\
\hline \multirow{2}{*}{ Table 3. $\begin{array}{l}\text { The loading forces and the corresponding indentation diameters } \\
\text { from the Brinell-test }\end{array}$} \\
3. táblázat \\
A terhelöerök és a benyomódási átmérök a Brinell vizsgálatok alapján
\end{tabular}

From the measured diameter values by knowing the loading force and the diameter of the indenter, the Brinell-hardness of the material can be computed by Eq. (1). Table 3 contains the Brinell-hardness values obtained experimentally.

$$
H B=\frac{2 \cdot F}{D \cdot \pi \cdot\left(D-\sqrt{D^{2}-d^{2}}\right)}
$$

where:

$\mathrm{HB}$ - Brinell-hardness $\left(\mathrm{N} / \mathrm{mm}^{2}\right)$,

$\mathrm{F}$ - loading force $(\mathrm{N})$,

$\mathrm{D}$ - diameter of steel ball ( $\mathrm{mm})$,

$\mathrm{d}$ - diameter of residual imprint ( $\mathrm{mm})$.

\section{Comparison of experimental and simulated results}

In the followings, experimental and simulated results are compared on the basis of the indentation diameter (d) and the Brinell-hardness (HB). 
The results of measured and simulated indentation diameters are shown in Fig. 5. The shape and the steepness of curve obtained from the DEM Brinell model follows quite well the laboratory test results. It can be seen in the figure, that the Brinell-hardness test and the DEM model results run sufficiently close to each other, differences can be seen only in case of low and high load levels. In case of medium forces the results are almost the same.

Special characteristics of hardness can be observed from the results of the DEM model as well. Fig. 6 shows the relationship between the loading force and the square of the indentation diameter. In the literature it was observed that the relationship between the square of indentation diameter and the loading force is linear. The reason for the use of the square of the indentation diameter can be found in the formula of the Brinell-hardness, where the loading force is divided with the surface area of the indentation, in which the indentation diameter appears with a power of two. Very similar behaviour can be observed if the indentation depth is shown in function of the loading force. The present laboratory tests confirm these observations and the DEM model results follow this behaviour too. The strong correlation can be confirmed by the trend lines added to the observed data (see Fig. 6). It shows that the correlation coefficient of the results is higher than 0.97 (97\%). Based on the literature, result can be considered statistically significant if the correlation coefficient is higher than $95 \%$.

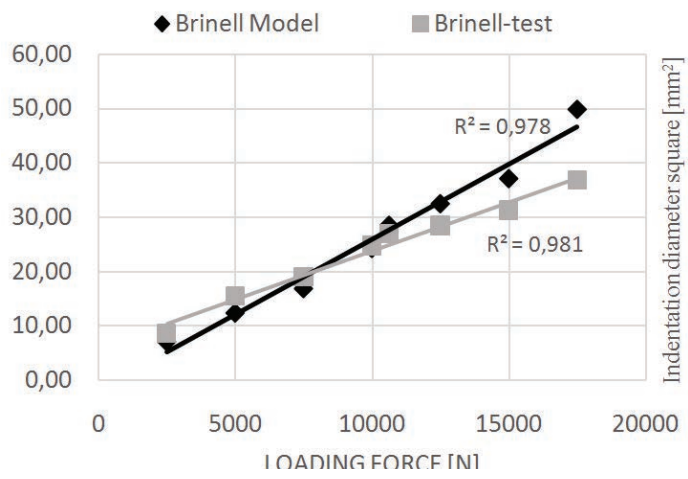

Fig. 6. Square of indentation diameter (model + Brinell test) vs. loading force

6. ábra Benyomódási átmérö négyzete (DEM modell + Brinell vizsgálat) és terhelöerö összefüggése

\section{Conclusions}

The DEM model presented in this study shows sufficient correlation with the experimental test results for the Brinellhardness testing of concrete. Various characteristics of hardness-testing can be observed with the use of the DEM model. It can be realized that the relationship of the loading force and the square of the indentation diameter is linear, which was observed in the literature in the past. Based on the findings it can be concluded that the Brinell-hardness of concrete can be modelled by using the model developed, especially at medium load levels. In case of low and high loads a slight difference can be observed of which reasons need further analyses. As a final conclusion of the study it can be stated that the developed DEM model of the Brinell-hardness testing approximates the laboratory results sufficiently and with the help of the model various characteristics of hardness-testing can be analysed numerically.

\section{Acknowledgements}

Authors express their gratitude to the Hungarian Scientific Research Fund (OTKA) for the financial support of the research project OTKA K 109233 and to the Itasca Consulting Group for providing the software.

\section{References}

[1] Hertz, H. (1881): Über die Berührung fester elastischer Körper. Journal für die reine und angewandte Mathematik, 1881/5, pp. 12-23.

[2] Chandler, H. (1999): „Hardness testing”. ASM International, $192 \mathrm{p}$.

[3] Cundall, P. A. (1971): A computer model for simulating progressive large scale movements in blocky rock systems. Procs. Symposium of the International Society of Rock Mechanics, Nancy, France, Vol. 1., Paper II-8

[4] Gyurkó, Z. - Bagi, K. - Borosnyói, A. (2014): Discrete Element Modelling of uniaxial compression test of hardened concrete. Épitöanyag-JSBCM, Vol. 66, No. 4, pp. 113-119.

http://dx.doi.org/10.14382/epitoanyag-jsbcm.2014.21

[5] Cundall, P. A. (1982): Adaptive density scaling for time-explicit calculations. Procs. 4th International Conference on Numerical Methods in Geomechanics, Edmonton, pp. 23-26.

[6] Cundall, P. A. (1988): Formulation of a three-dimensional distinct element model - Part I: A scheme to detect and represent contacts in a stem composed of many polyhedral blocks. Int. J. Rock Mech. Min. Sci. \& Geomech. Abst., Vol. 25, pp. 107-116.

[7] Itasca Consulting Group (2007): 3 Dimensional Distinct Element Code. Users Guide. Minneapolis, Minnesota, USA

[8] Itasca Consulting Group (2008): Particle Flow Code in Three Dimensions. Users Guide, Minneapolis, Minnesota, USA,

[9] Itasca Consulting Group (2011): Universal Distinct Element Code. Users Guide, Minneapolis, Minnesota, USA

[10] Bagi, K. (1993): A quasi-static numerical model for micro-level analysis of granular assemblies. Mechanics of Materials, Vol. 16. pp. 101-110.

\section{$\underline{\text { Ref.: }}$}

Gyurkó, Zoltán - Borosnyói, Adorján: Brinell-hardness testing and Discrete Element Modelling of hardened concrete Építőanyag - Journal of Silicate Based and Composite Materials, Vol. 67, No. 1 (2015), 8-11. p. http://dx.doi.org/10.14382/epitoanyag-jsbcm.2015.2

\section{Megszilárdult beton Brinell keménység mérésének} modellezése diszkrét elemes eljárással

A diszkrét elemes módszer (DEM) az elmúlt évtizedekben vált ismertté a mérnöki gyakorlatban, mint az elsôsorban szemcsés anyagok vagy diszkrét felépítésũ szerkezetek (elsôsorban falazott szerkezetek) modellezésére használatos numerikus eljárás. A DEM segítségével nagy számú, többnyire kis méretũ elem mozgását lehet kiszámítan az ôket érô hatásokból. Ebben a numerikus módszerben a modellt felépítô elemek egymástól különállóak, egymástól függetlenül szabadon elmozdulhatnak, valamint egymással kapcsolatba léphetnek. Jelen tanulmány készítése során fontos célkitũzés volt egy, a beton adalékanyagának szemeloszlását pontosan követố modell létrehozása. Ezért is volt fontos egy olyan modellezési eljárás választása, amelynek segítségével adalékanyag frakciókat lehet követni megfelelố pontossággal. A kutatás eredménye alapján megállapítható, hogy a DEM modell jól közelítette a normál beton nyomószilárdságának és statikus keménység vizsgálatainak valós kísérleti eredményeit. A modell képes volt a beton adalékanyag szemeloszlásának követésére, amely a vizsgála egyik alapkövetelménye. A keménységmérési eljárások modellezése során csak a leg kisebb illetve legnagyobb terhelố erỗ esetén volt megfigyelhetố eltérés, a közbensố értékek esetén a DEM modell eredmények jól közelítették a laboratóriumi vizsgálatok eredményeit. A modellezési eredményeken szintén kimutatható több, a múltban a szakirodalomban megfigyelt, keménységgel kapcsolatos jelenség, mint pl. a benyomódás átmérô négyzetének és a terhelō erônek a lineáris összefüggése. Mindezek alapján levonható a következtetés, hogy a diszkrét elemek módszere egy jól használható módszer porózus szilárd anyagok modellezésére is.

Kulcsszavak: Brinell keménység, Diszkrét Elemes eljárás, beton, porózus szilárd anyagok, benyomódás vizsgálat 